\title{
Pensonomonoor
}

2020, vol. 84, 49-57

https://doi.org/10.12657/denbio.084.005

\author{
Mustafa Yilmaz, Mehmet Kalkan*, Hakan Demirbă̆
}

\section{Seed characteristics of Amygdalus arabica in Adiyaman region of Turkey}

\author{
Received: 13 July 2020; Accepted: 20 November 2020
}

\begin{abstract}
Mountain almond (Amygdalus arabica) is a shrub with naturally distributing in Turkey, Iran, Iraq, Syria, Jordan and Saudi Arabia. A. arabica also known as bitter almond and can reach up to $2.5 \mathrm{~m}$. The natural distribution of mountain almond is generally in the Southeast Region of Turkey. The present study carried out to determine the morphological and physiological characteristics of the seed of mountain almond. The seeds were collected from three different populations of $A$. arabica in Adiyaman. For different each populations seed weight, height, width, thickness, and 1000-seed weight were measured in the laboratory. Morphological characteristics of $A$. arabica seeds varied according to their populations. Seed germination tests were conducted at $20^{\circ} \mathrm{C}$, after prechilling for $0,3,6$, and 9 weeks at $4{ }^{\circ} \mathrm{C}$. Prechilling treatments of 3 weeks were insufficient, but 6 and 9 weeks of prechilling were found to eliminate seed dormancy and led to the highest germination percentage. The average germination percentage after $0,3,6$, and 9 weeks of prechilling were $3.1 \%, 49.6 \%, 80.4 \%$, and $81.1 \%$, respectively. The average mean germination time was approximately between 8 and 10 days.
\end{abstract}

Keywords: mountain almond tree, hot-arid areas, seed germination, prechilling, dormancy

Address: M. Yilmaz, M. Kalkan, H. Demirbağ, Bursa Technical University, Faculty of Forestry, Department of Silviculture, Bursa 16310 Turkey, e-mail: mehmet.kalkan@btu.edu.tr

*Corresponding author

\section{Introduction}

Mountain almond (Amygdalus arabica Olivier) is a shrub with naturally distributing in Turkey, Iran, Iraq, Syria, Jordan and Saudi Arabia (Fig. 1). A. arabica can reach up to $2.5 \mathrm{~m}$. and also known as Bitter almond (Yaltırık, 1971; Kester \& Asay, 1975; Kester et al., 1991; Browicz \& Zohary, 1996). The natural distribution of mountain almond is generally in the Southeast Region of Turkey. The under and upper surface of $10-40 \mathrm{~mm}$ length and 3-5 mm thick leaves are felt-like feathered as a sign of drought resistance. Fruits are spherical or egg-shaped (ellipsoid) about $2.5 \mathrm{~cm}$ long. The A. arabica generally has ellipsoid (A. arabica var. spartioides) shaped fruit structure in Turkey (Davis, 1972; Browicz \& Zohary, 1996). Its distribution in the region is generally between 500 $1650 \mathrm{~m}$ (Demirbağ et al., 2018). It is frequently seen in areas eroded, on dry stony slopes, in forested areas and steppe environments and on road slopes in the region. Fruits are edible while fresh, almond (seed) is not eaten because of bitter taste (Meikle, 1966; Yaltırık, 1971; Browicz \& Zieliński, 1984). Flowering takes place in March-April (Davis, 1972; Yildız, 2013). The flowers are individual, stemless and appear before leafing. It is a broom-like shrub (Miller \& Cope, 1996).

This species, which is found in poor regions in terms of woody species, also supports the wildlife in the region. It is used as firewood in places where there is a limited burning material. A. arabica is a species that can sustain its existence even on poor 


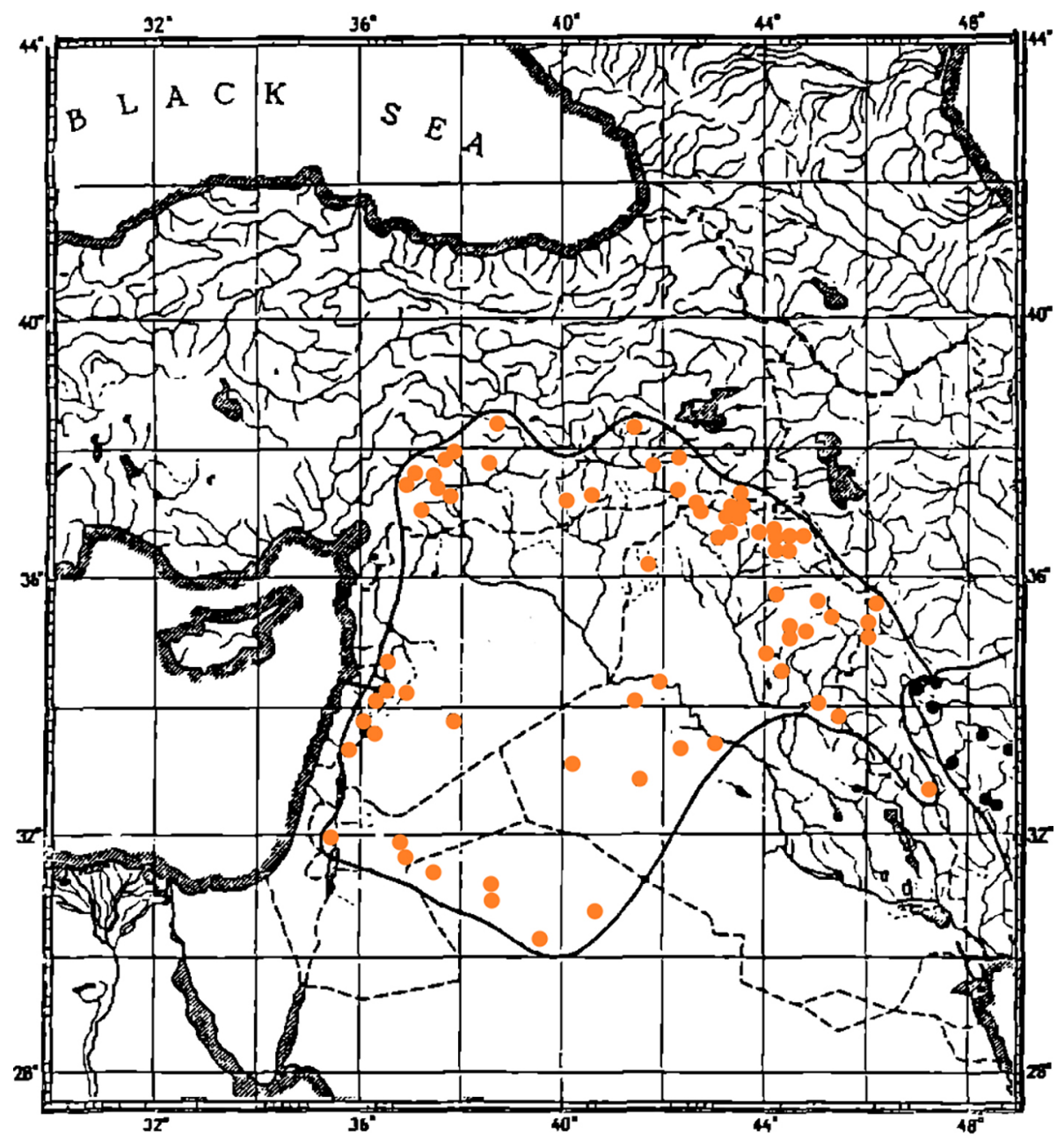

- A. arabica Olivier

Fig. 1. The distribution of A. arabica in Turkey, Iran, Iraq, Syria, Jordan and Saudi Arabia (Browicz \& Zohary, 1996)

soil. The roots of shrub reach into deep and hold soil even in the riskiest areas of erosion. The species is a very valuable native plant material for the plantation of stony, rocky fields and the slopes with the risk of erosion especially around natural distribution areas (Yaltırık, 1971; Browicz \& Zieliński, 1984; Grasselly, 1990).

The studies on mountain almonds have been increasing in recent years due to its usefulness for different purposes in difficult places (Gholami et al., 2010; Hosenzadeh \& Saeb, 2011; Bayazit et al., 2011; Rahemi et al., 2009; Y1ld1z, 2013; Goujani et al., 2013; Köse et al., 2015; Akgün et al., 2018, Kayra et al., 2018). A. arabica is very useful plant material for the hot-arid regions due to its resistance to extreme drought conditions. The suitable populations in high altitudes are also available to be used in the planting of cold-arid areas.

There have been several studies on the germination of almond species seeds using different techniques and methods. (Khalil \& Al-Eisawi, 1998; Garcia-Gusano et al., 2004; Rouhi et al., 2005a; Rouhi et al., 2005b; Rahemi et al., 2009; Gholami et al., 2010; Hosenzadeh \& Saeb 2011; Kayra et al., 2018). Amygdalus arabica seed germination has been studied with bioregulators in a few studies (Khalil \& Al-Eisawi, 1998; Rahemi et al., 2009) but neither extensively studied on the morphological nor physiological characteristics of its seeds.

In this study, physiological and morphological (weight, length, width and thickness) characteristics of mountain almond seeds collected from three different populations in Adiyaman region of Turkey were investigated. The dormancy and depth of dormancy in $A$. arabica seeds were examined. In addition, it was hypothized that there are degrees of variations between populations in terms of seed morphological and physiological characteristics.

\section{Materials and Methods}

The fully mature fruits were collected from three populations of Amygdalus arabica in southern Turkey 
in July, 2019 (Table 1; Fig. 2). The collected fruits were packed in plastic bags and stored under laboratory conditions.

Mountain almond fruits were dried at room temperature in the laboratory and the seeds are extracted from their husks (mesocarp). The seeds dried for about 1 week until their moisture content was reduced to $8 \%$ and then stored in a refrigerator within bottles.

\section{Measurement of morphological characteristics of seeds}

Morphological measurements were performed on 100 seeds randomly selected from each population.
Length, width, thickness, and weight were measured in each seed. Measurements were carried out with $0.0000 \mathrm{~g}$ and $0.00 \mathrm{~mm}$ sensitivity. The endocarp thickness and embryo/seed ratio (ESR) were determined. Also, according to the rules of ISTA (2019), 1000 seed weights from $800(8 \times 100)$ seeds were calculated.

\section{Dormancy level and pretreatments}

In order to determine the dormancy level and prechilling time of the species, the seeds collected from three different populations (Table 1) were prechilled at $4{ }^{\circ} \mathrm{C}$ in incubators for 0 (Control), 3, 6, and 9 weeks.
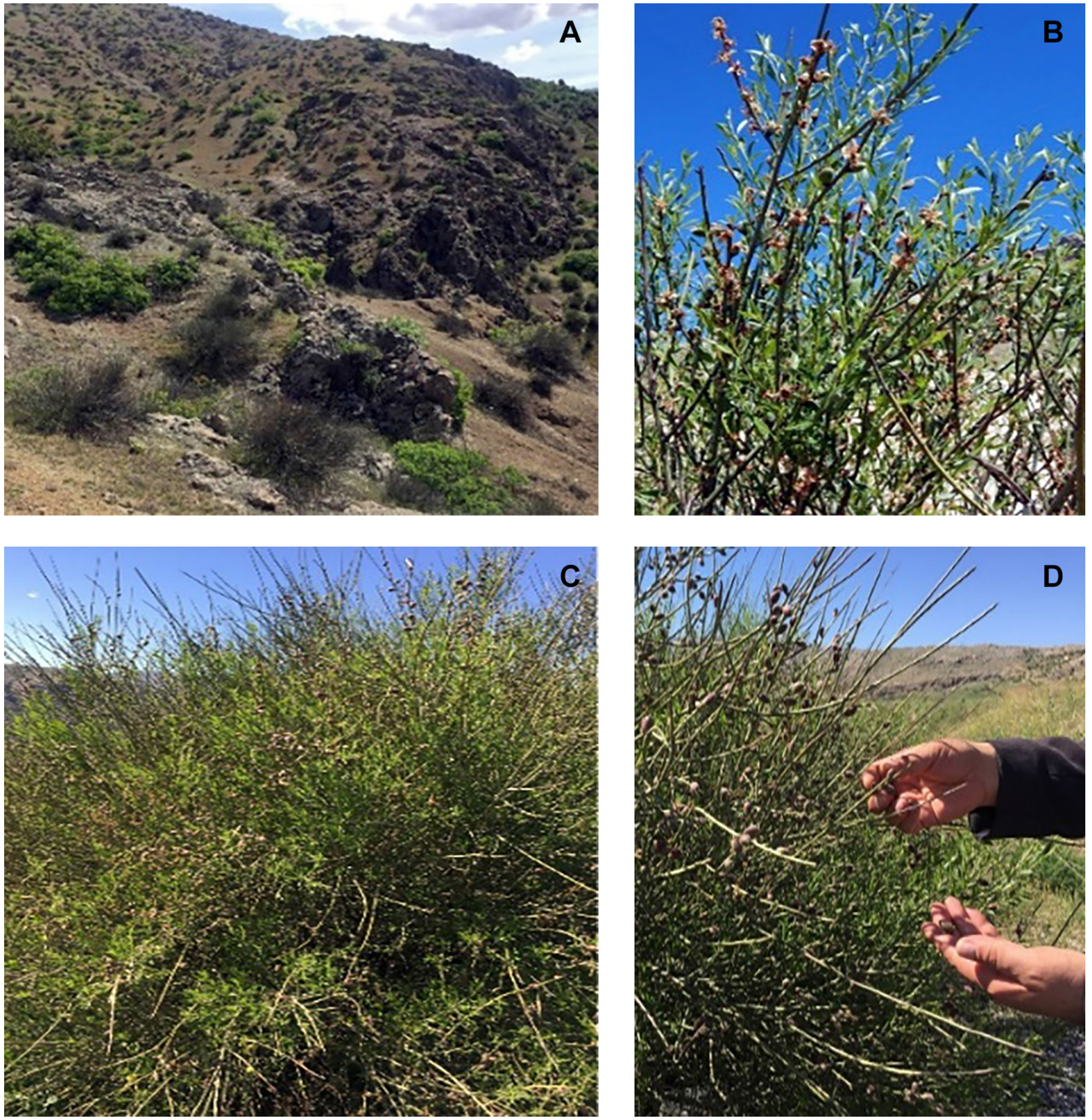

Fig. 2. Natural distribution sites of A. arabica (A), flower and fruit (B, C) and the collection of mature fruit (D)

Table 1. Information on the collected seed materials

\begin{tabular}{|c|c|c|c|c|c|}
\hline Populations & Seed collection date & Latitude & Longitude & Altitude $[\mathrm{m}]$ & Aspect \\
\hline Akyazı & July 18, 2019 & $37^{\circ} 30^{\prime}$ & $38^{\circ} 17^{\prime}$ & 580 & South \\
\hline Çemberlitaş & July 20, 2019 & $37^{\circ} 48^{\prime}$ & $38^{\circ} 18^{\prime}$ & 770 & South \\
\hline Yassıkaya & July 23, 2019 & $37^{\circ} 55^{\prime}$ & $38^{\circ} 36^{\prime}$ & 630 & South \\
\hline
\end{tabular}


During prechilling $\left(4^{\circ} \mathrm{C}\right)$, distilled water was added with spray when necessary to prevent moisture deficiency in Petri dishes with a double-layer filter paper on which seeds were placed.

\section{Germination test}

Germination tests were performed in glass Petri dishes ( $12 \mathrm{~cm}$ diameter) in incubators at $20^{\circ} \mathrm{C}$ with 150 seeds ( 3 dishes $\times 50$ seeds) on double-layer filter paper. As a result of the preliminary tests, the suitable germination temperature for the seeds of the species was determined as $20^{\circ} \mathrm{C}$. Before the germination test, the seeds were kept in $10 \%$ sodium hypochlorite $(\mathrm{NaClO})$ solution for 10 minutes in order to prevent fungal and bacterial infections. After surface sterilization, the seeds were washed three times with sterile distilled water (Cantos et al., 1998; Işıkalan et al., 2008). Filter papers were replaced when a fungal infection occurred. The seeds were considered germinated when the seed radicles were about $3 \mathrm{~mm}$ and geotropism was observed. Once every two days, Petri dishes were checked. The germinated seeds were recorded and removed. Germination tests were terminated after 28 days.

\section{Germination parameters}

The germination percentage (GP) and mean germination time (MGT) were calculated by the following formulas during germination tests (Bewley et al., 2013):

$$
G P(\%)=\frac{\sum n_{i}}{N} \times 100
$$

- GP (\%): Germination percentage,

- $n_{i}$ : The number of germinated seeds at day $i$,

- $\quad N$ : The total number of incubated seeds per test.

$$
M G T=\frac{\sum\left(t_{i} \times n_{i}\right)}{\sum n_{i}}
$$

- MGT: The mean germination time,

- $t_{i}$ : The number of days since the beginning of the test,

- $n_{i}$ : The number of germinated seeds recorded for day $t_{i}$.

\section{Statistical analyses}

The data of seed weight, length, width, thickness, 1000-seed weight, germination percentage and mean germination time were evaluated by analyses of variance. One-Way ANOVA test was performed to reveal the interaction of prechilling and population factors in all of the data obtained after the germination test.
GP values were transformed using arcsine formula to normalize error distribution prior to variance analyses. Differences among groups were determined using Duncan's multiple range test when a significant effect was identified.

\section{Results}

\section{Morphological characteristics of the seeds}

In terms of morphological features, A arabica seeds have been determined to significant differences (Table 2, Fig. 4). The average seed length, width, thickness, and weight were $14.99 \mathrm{~mm}, 10.57 \mathrm{~mm}$, $7.89 \mathrm{~mm}$, and $0.546 \mathrm{~g}$ respectively. In terms of seed weight from the populations were determined respectively as the heaviest to lightest; Çemberlitaş, Akyazı, and Yassıkaya. The average 1000-seed weight at about $8 \% \mathrm{MC}$ for the three populations was 487.6 grams.

Also, the average of embryo/seed ratio, endocarp weight, embryo weight and endocarp thickness were $36.65 \%, 0.354 \mathrm{mg}, 0.203 \mathrm{mg}, 1.07 \mathrm{~mm}$ respectively (Table 3). The seed in the tables and texts is the material extracted from the fruit with endocarp and embryo inside. The endocarp, a hard shell, is the hard structure that protects the embryo. In this study, the embryo is the entire part under the endocarp. For practical purposes, the weight of the seed coat was included in the embryo weight (Fig. 3).

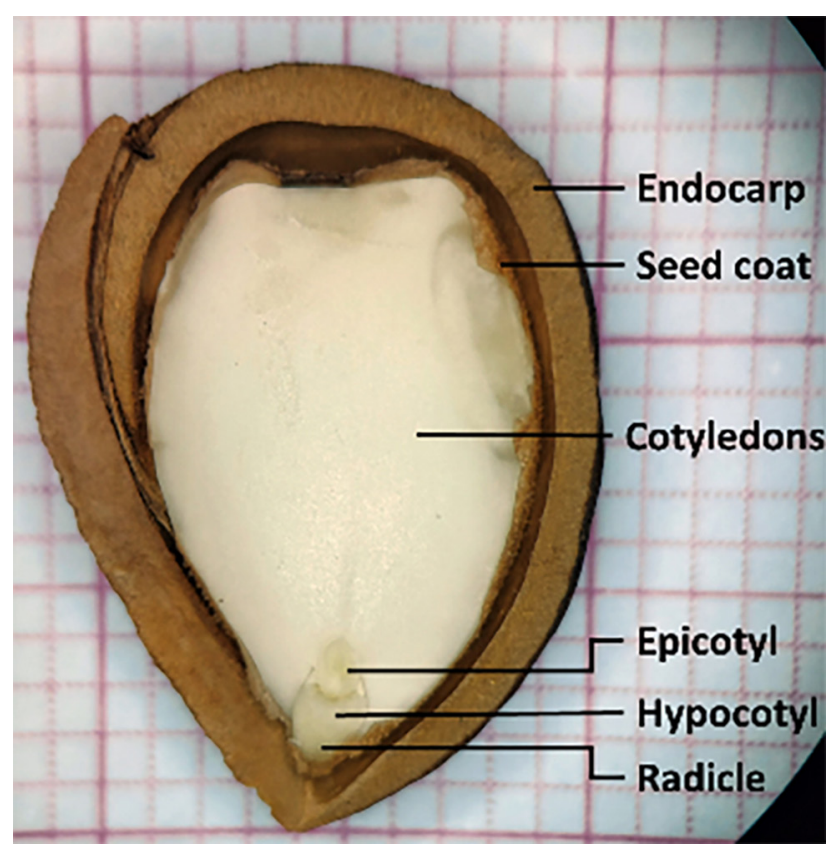

Fig. 3. Section through an A. arabica seed with a visible embryo inside 
Table 2. Morphological characteristics of the A. arabica seeds

\begin{tabular}{cccccc}
\hline Populations & Length [mm] & Width $[\mathrm{mm}]$ & Thickness [mm] & Weight [g] & 1000-seed weight [g] \\
\hline Akyazı & $15.34 \mathrm{a}$ & $10.39 \mathrm{a}$ & $7.66 \mathrm{c}$ & $0.542 \mathrm{ab}$ & 487.6 \\
Çemberlitaş & $14.75 \mathrm{~b}$ & $10.68 \mathrm{a}$ & $7.91 \mathrm{~b}$ & $0.573 \mathrm{a}$ & 498.8 \\
Yassıkaya & $14.87 \mathrm{ab}$ & $10.65 \mathrm{a}$ & $8.12 \mathrm{a}$ & $0.523 \mathrm{~b}$ & 494.2 \\
Average & 14.99 & 10.57 & 7.89 & 0.546 & 487.6 \\
\hline
\end{tabular}

${ }^{1}$ The values on the same column followed by the same small letters are not significantly different at $\mathrm{P}<0.05$.

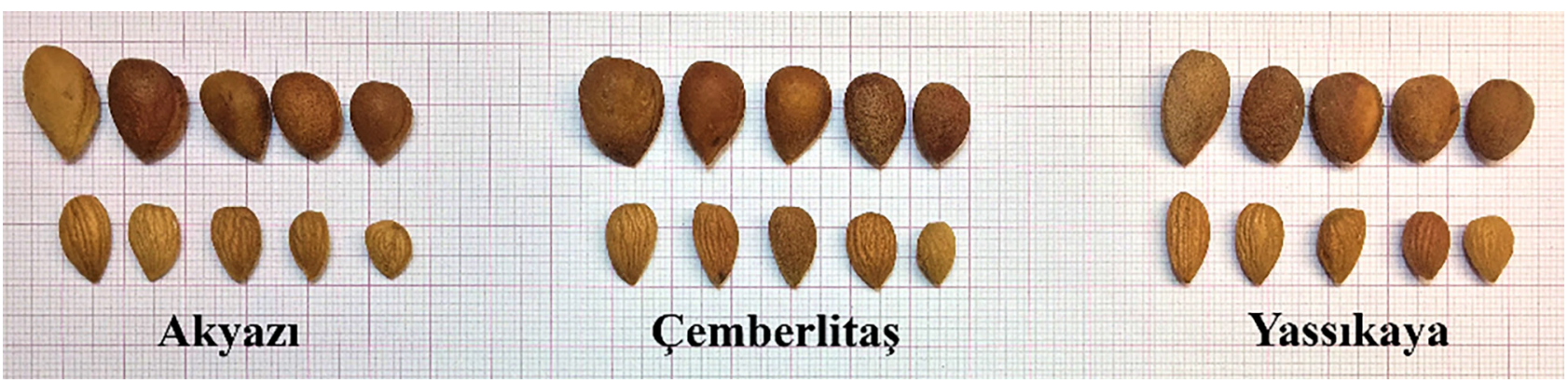

Fig. 4. Different size of seeds (upper) and embryos (bottom) from three different populations

\section{Dormancy level and prechilling requirements}

The germination percentage and mean germination times of $A$. arabica seeds were significantly affected by both the prechilling and population. The prechilling $\times$ population interaction effect was also significant on GP and MGT $(\mathrm{P}<0.01)$ (Table 4).
Significant differences were determined between the prechilling treatments in terms of the germination percentage of seeds germinated at $20{ }^{\circ} \mathrm{C}$. Prechilling treatments of $3 \mathrm{w}$ were insufficient, but 6 and $9 \mathrm{w}$ of prechilling were found to eliminate seed dormancy and led to the highest GP. The average germination rates after 0 (Control), 3, 6, and 9 weeks of prechilling were $3.1 \%, 49.6 \%, 80.4 \%$, and $81.1 \%$, respectively (Table 5, Fig. 5).

Table 3. Seed, endocarp and embryo weights and embryo/seed ratio values of the populations

\begin{tabular}{lccccc}
\hline \multicolumn{1}{c}{ Populations } & Seed weight [g] & Endocarp weight $[\mathrm{g}]$ & Embryo [g] & Embryo/Seed Ratio [\%] & Endocarp thickness [mm] \\
\hline Akyazı & $0.550 \mathrm{a}$ & $0.352 \mathrm{a}$ & $0.198 \mathrm{ab}$ & $36.22 \mathrm{ab}$ & $1.24 \mathrm{a}$ \\
Çemberlitaş & $0.555 \mathrm{a}$ & $0.337 \mathrm{a}$ & $0.218 \mathrm{a}$ & $39.24 \mathrm{a}$ & $0.88 \mathrm{c}$ \\
Yassıkaya & $0.567 \mathrm{a}$ & $0.372 \mathrm{a}$ & $0.194 \mathrm{~b}$ & $34.49 \mathrm{~b}$ & $1.10 \mathrm{~b}$ \\
Average & 0.557 & 0.354 & 0.203 & 36.65 & 1.07 \\
\hline
\end{tabular}

${ }^{1}$ The values on the same column followed by the same small letters are not significantly different at $\mathrm{P}<0.05$.

Table 4. Effects of the prechilling and population on germination percentage (GP) and mean germination time (MGT) of A. arabica

\begin{tabular}{lccccccc}
\hline \multirow{2}{*}{ Source } & \multicolumn{3}{c}{ GP } & \multicolumn{3}{c}{ MGT } \\
\cline { 2 - 7 } & $\mathrm{df}$ & MS & $\mathrm{F}$ & $\mathrm{p}$-value & MS & $\mathrm{F}$ & $\mathrm{p}$-value \\
\hline Prechilling (A) & 3 & 6019.2 & 544.4 & 0.000 & 508.17 & 251.93 & 0.000 \\
Population (B) & 2 & 93.4 & 8.4 & 0.002 & 22.03 & 10.92 & 0.000 \\
$\mathrm{~A} \times \mathrm{B}$ & 6 & 125.6 & 11.3 & 0.000 & 7.85 & 3.89 & 0.007 \\
Error & 24 & 11.1 & & & 2.02 & & \\
\hline
\end{tabular}

Table 5. Germination percentage for A. arabica seeds at $20^{\circ} \mathrm{C}$ after 4 prechilling regimes

\begin{tabular}{lcccc}
\hline \multirow{2}{*}{ Populations } & \multicolumn{4}{c}{ Prechilling duration } \\
\cline { 2 - 4 } & 0 (control) & 3 weeks & 6 weeks & 9 weeks \\
\hline Akyazı & $2.7 \mathrm{c}^{1}$ & $42.7 \mathrm{~b}$ & $82.0 \mathrm{a}$ & $80.7 \mathrm{a}$ \\
Çemberlitaş & $4.0 \mathrm{c}$ & $60.7 \mathrm{~b}$ & $69.3 \mathrm{a}$ & $71.3 \mathrm{a}$ \\
Yassıkaya & $2.7 \mathrm{c}$ & $45.3 \mathrm{~b}$ & $90.0 \mathrm{a}$ & $51.3 \mathrm{~A}$ \\
Average & $3.1 \mathrm{C}^{2}$ & $49.6 \mathrm{~B}$ & $80.4 \mathrm{~A}$ & $51.3 \mathrm{a}$ \\
\hline
\end{tabular}

${ }^{1}$ The values on the same row followed by the same small letters are not significantly different at $\mathrm{p}<0.05$.

${ }^{2}$ The values on the same row followed by the same capital letters are not significantly different at $p<0.05$.

${ }^{3}$ The values on the same column followed by the same capital letters are not significantly different at $\mathrm{p}<0.05$. 
Table 6. Mean germination times (day) of $A$. arabica seeds after different prechilling regimes

\begin{tabular}{lccccc}
\hline \multirow{2}{*}{ Populations } & \multicolumn{4}{c}{ Prechilling duration } & \multirow{2}{*}{ Average } \\
\cline { 2 - 4 } & 0 (control) & 3 weeks & 6 weeks & 9 weeks & $10.3 \mathrm{~A}^{3}$ \\
Akyazı & $23.7 \mathrm{c}^{1}$ & $8.7 \mathrm{~b}$ & $4.4 \mathrm{a}$ & $4.5 \mathrm{a}$ & $7.7 \mathrm{~A}$ \\
Çemberlitaş & $16.6 \mathrm{C}$ & $5.9 \mathrm{~b}$ & $4.0 \mathrm{a}$ & $4.2 \mathrm{a}$ & $8.5 \mathrm{~A}$ \\
Yassıkaya & $19.3 \mathrm{C}$ & $7.4 \mathrm{~b}$ & $3.7 \mathrm{a}$ & $3.6 \mathrm{a}$ & 8.8 \\
Average & $19.9 \mathrm{C}^{2}$ & $7.4 \mathrm{~B}$ & $4.0 \mathrm{~A}$ & $4.1 \mathrm{~A}$ & \\
\hline
\end{tabular}

${ }^{1}$ The values on the same row followed by the same small letters are not significantly different at $\mathrm{p}<0.05$.

${ }^{2}$ The values on the same row followed by the same capital letters are not significantly different at $\mathrm{p}<0.05$.

${ }^{3}$ The values on the same column followed by the same capital letters are not significantly different at $\mathrm{p}<0.05$.

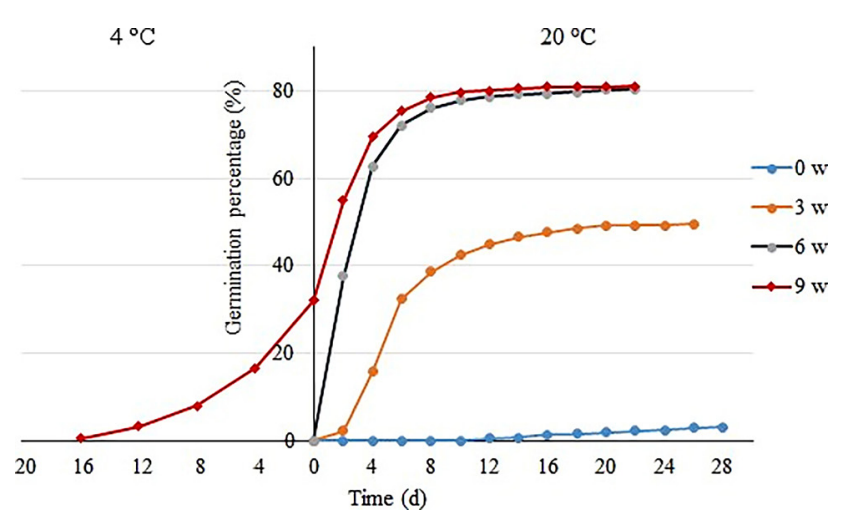

Fig. 5. Average germination percentage of $A$. arabica seeds (w - week, d - day)

The germination percentage was very low in the $0 \mathrm{w}$ (control) without prechilling. About half of the seeds germinated with $3 \mathrm{w}$ prechilling duration. Following the $6-\mathrm{w}$ and $9-\mathrm{w}$ prechilling durations have almost similar germination percentage. In addition, seeds started to germinate at $4{ }^{\circ} \mathrm{C}$ in the late of $9 \mathrm{w}$ prechilling duration.

The prechilling duration also affected the time required to germinate. In general, longer prechilling time eliminates the seed dormancy more easily and led to earlier germination. The average MGT was approximately between 8 and 10 days. There was no statistically important differences for MGT between populations. (Table 6).

\section{Discussion}

This study of seed characteristics of A arabica revealed the morphological seed characteristics, the depth of dormancy and the effects of prechilling duration on the germination behavior. Although germination tests terminated after 28 days, experiments showed that the three-week test period was sufficient germination time for $A$. arabica seeds.

Significant differences were identified in the three populations examined according to mountain almond seed morphological characteristics (Table 2 ). The seed length, weights and thicknesses varied between populations. This result is consistent with the hypothesis that one of the factors affecting seed morphology is the habitat variation of a species. (Fenner \& Thompson, 2005).

A. arabica fruit are generally smaller than most of other Amygdalus species. According to the average fruit length-width, A. arabica (15-10 mm) is smaller than A. lycioides (17-9 mm), A. orientalis (25-16 mm) and $A$. communis (46-27 mm) (Karataş, 2007; Köse, 2014). The result of the morphological measurements of the three populations of A. arabica seeds, the average length and width were determined as $14.99 \mathrm{~mm}$ and $10.57 \mathrm{~mm}$, respectively. The average 1000 -seed weight of $A$. arabica for the three populations (487.6 g) was roughly similar to the previously recorded average 1000-seed weight of the species (449.4 g) (RBG, 2020).

In the ecology of a plant species, seed dimensions are vital for maintaining viability. The main determinant of seed dimension and shape are genetic characteristics and environmental factors (Leishman et al., 2000; Flores, 2002; Desai, 2004). The seed mass is also highly dependent on environmental conditions during seed development (Michaels et al., 1988; Castro et al., 2006). In this study, in terms of seed dimension, significant variations were determined within and among the populations. Similar studies have been reported in many other studies in the literature and almond species including Amygdalus arabica Oliv., Amygdalus orientalis Mill., and Amygdalus turcomonica Lincz. (Köse et al., 2015), Amygdalus communis L. (Talhouk et al., 2000), A. orientalis Mill. (Shalaby et al., 1997), A. orientalis Mill. and A. turcomenica Lincz. (Ak et al., 2001), A. orientalis Mill. and A. turcomenica Lincz. (Bayazı1, 2007).

Generally, the depth of dormancy varies depending on the species, the habitat of the species or individuals of the same locality (Bewley \& Black, 1994; Copeland \& McDonald, 1999; Schmidt, 2000; Bewley et al., 2013). In the prechilling period, 3-week prechilling was insufficient to eliminate the presence of dormancy of $A$. arabica seeds. However, 6 to 9 weeks prechilling showed full germination potential in the seeds. After 6 weeks prechilling, the seeds obtained from three populations had similar dormancy of depth and germination rates. Similarly, prechilling between 45 or 60 days has been determined to be sufficient on the germination of $A$. arabica in a study 
by Khalil and Al-Eisawi (1998). The experiments suggest that 6 weeks of prechilling is sufficient for $A$. arabica seeds to break the dormancy.

Generally, warm incubation is used for seeds that have morphological dormancy. (Baskin \& Baskin, 2004). This study showed that having only a physiological dormancy of mature A. arabica seeds (ripen around July) that requires about 6 weeks of prechilling for germination. Although mountain almond has a thick endocarp (Table 3), it has been detected that there is no physical dormancy due to the easy entry of moisture and air from the endocarp.

The distribution range of the species is closely related to the depth of seed dormancy (Schmidt, 2000; Baskin \& Baskin, 2001; Fenner \& Thompson, 2005). In this study, the seeds from the three populations demonstrated a similar depth of dormancy, likely because of their relatively close distribution in a limited area of the southern of Turkey.

The germination temperature, very effective factor on seed germination parameters, is highly related to the ecology and the distribution range of the species (Fenner \& Thompson, 2005; Yllmaz, 2010). The preliminary tests and the study demonstrated that germination test at $20{ }^{\circ} \mathrm{C}$ is a suitable temperature for the seed germination of $A$. arabica, mainly distributed in hot-arid areas. On the other hand, the seeds of many plants cannot germinate at low temperature such as $4{ }^{\circ} \mathrm{C}$. Khalil and Al-Eisawi (1998), obtained significantly highest germination percentage (63$67 \%$ ) on A arabica seeds after prechilling at 45-60 days at $5{ }^{\circ} \mathrm{C}$. In this study, the seeds were started to germinate at $4{ }^{\circ} \mathrm{C}$ in the late of $9 \mathrm{w}$ prechilling duration after the complete elimination of dormancy. This indicates that A. arabica can adapt to the relatively cold areas.

This study also showed that $A$. arabica seeds have a deep physiological dormancy. Also, the seed sowing time is critical in the forest nursery in Turkey. The dormancy of seeds naturally eliminates during the winter. For seed propagation, the dormant seeds of $A$. arabica should be sown around the beginning of January. On the other hand, nondormant seeds could also be sown in the spring after approximately 6 weeks of prechilling. A. arabica seeds are dry stored (orthodox) seeds (RBG, 2020). Dry seeds of the species can easily be stored in seed banks for the long period (Yılmaz et al., 2014; Yılmaz \& Ok, 2015).

The species is a very valuable native plant in hot-arid regions with extreme growing conditions. This study demonstrated that the seeds need about 6-week chilling pretreatment and are not difficult to germinate. A. arabica should be used in the plantation of stony, rocky, and the slopes with the risk of erosion especially around natural distribution areas. The suitable populations at high altitudes can also be one of the best seed origins in the planting of cold-arid areas. In addition, a couple of dense populations of this neglected species should be reserved as a genetic conservation sites.

\section{References}

Ak BE, Acar I, \& Sakar E (2001) An investigation on the determination of pomological and morphological traits of wild almond grown at Sanliurfa province: XI GREMPA Seminar on Pistachios and Almonds, vol. 56, pp. 139-145.

Akgün B, Yazar E \& Kocacinar F (2018) Photosynthetic responses of Amygdalus arabica Olivier and Atriplex canescens (Pursh) nutt to drought stress under field conditions. Sibirskij Lesnoj Zurnal/Siberian Journal of Forest Science 6: 103-111.

Baskin CC \& Baskin JM (2001) Seeds: ecology, biogeography, and evolution of dormancy and germination. Elsevier.

Baskin JM \& Baskin CC (2004) A classification system for seed dormancy. Seed Science Research 14: $1-16$.

Bayazit S (2007) Türkiye'nin Farklı Ekolojilerindeki Yabani Badem Genotiplerinde Fenolojik, Morfolojik ve Pomolojik Özellikler ile Moleküler Yapıların Tanımlanması. Fen Bilimleri Enstitüsü, Bahçe Bitkileri Anabilim Dalı, Adana.

Bayazit S, Caliskan O \& Imrak B (2011) Comparison of pollen production and quality characteristics of cultivated and wild almond species. Chilean Journal of Agricultural Research 71: 536-541.

Bewley JD \& Black M (1994) Seeds: physiology of development and germination. Plenum Press, New York.

Bewley JD, Bradford KJ, Hilhorst HWM \& Nonogaki H (2013) Seeds: physiology of development, germination and dormancy. 3rd ed. Springer, New York.

Browicz K \& Zieliński J (1984) Chorology of trees and shrubs in South-west Asia and adjacent regions. Polish Scientific Publishers.

Browicz K \& Zohary D (1996) The genus Amygdalus L. (Rosaceae): Species relationships, distribution and evolution under domestication. Genetic Resources and Crop Evolution 43: 229-247.

Cantos M, Cuerva J, Zárate R \& Troncoso de Arce A (1998) Embryo rescue and development of Juniperus oxycedrus subsp. oxycedrus and macrocarpa. Seed Science and Technology 26: 193-198.

Castro J, Hódar JA \& Gómez JM (2006) Seed size: Handbook of seed science and technology (ed. by AS Basra) Haworth Press, New York, pp. 397-427. Copeland LO \& McDonald MB (1999) Seed science and technology. Kluwer Academic Publishers, Boston. 
Davis PH (1972) Flora of Turkey and the East Aegean Islands. Vol. 3. Flora of Turkey and the East Aegean Islands.

Demirbağ H, Kalkan M \& Yılmaz M (2018) Adıyaman Yöresindeki Arap bademi (Amygdalus arabica) Gen Kaynakları, 4. Uluslararası Odun Dişı Orman Ürünleri Sempozyumu, 4-6 Ekim 2018 Bursa/ Türkiye.

Desai BB (2004) Seeds handbook: biology, production, processing, and storage. 2nd ed. Marcel Dekker, New York.

Fenner M \& Thompson K (2005) The ecology of seeds. Cambridge University Press, Cambridge.

Flores EM (2002) Seed biology: Tropical tree seed manual, USDA (ed. by JA Vozzo) Forest Service Agriculture Handbook 721, pp. 82-106.

Garcia-Gusano M, Martinez-Gomez P \& Dicenta F (2004) Breaking seed dormancy in almond (Prunus dulcis (Mill.) D.A. Webb). Scientia Horticulturae 99: 363-370.

Gholami M, Rahemi M \& Kholdebarin B (2010) Effect of drought stress induced by polyethylene glycol on seed germination of four wild almond species. Australian Journal of Basic and Applied Sciences 4: 785-791.

Goujani HJ, Nasr SMH, Sagheb-Talebi K \& Hojjati SM (2013) Effect of drought stress induced by altitude, on four wild almond species. Iranian Journal of Forest and Poplar Research 21: 373-386.

Grasselly C (1990) Almond production and industry in Europe, North Africa and the Middle East: Nut production and industry in Europe, Near East and North Africa. FAO, REUR Technical Series 13: 95-105.

Hosenzadeh J \& Saeb K (2011) Morphological diversity of Amygdalus arabica Oliv. in natural forests of Ilam province, Iran. Journal of Biodiversity and Ecological Sciences 1: 245-248.

ISTA (2019) International rules for seed testing. Chapter 10: Thousand-seed weight (TSW) determination, i-10-2 (8).

Isikalan C, Akbas FA, Namli S, Tilkat E \& Basaran D (2008) In vitro micropropagation of almond (Amygdalus communis L. cv. Nonpareil). African Journal of Biotechnology 7: 1875-1880.

Karataş S (2007) Şanlıurfa il sınırları içerisindeki Amygdalus L. (Rosaceae) türlerinin ekolojik, morfolojik ve anatomik özellikleri. Harran Üniversitesi, Fen Bilimleri Enstitüsü, Yüksek Lisans Tezi.

Kayra R, Atli HS \& Yavic A (2018) Determination of propagation statue of Amygdalus arabica Oliv. almond species grown in Siirt province. Fresenius Environmental Bulletin 27: 9345-9351.

Kester DE \& Asay R (1975) Almonds. Advances in fruit breeding. (ed. by J Janick \& JN Moore). Purdue University Press, Westlafeyette, İndiana, pp. 387-418.
Kester DE, Gradziel TM \& Grasselly C (1991) Almonds (Prunus). Genetic Resources of Temperate Fruit and Nut Crops 290: 701-760.

Khalil RY \& Al-Eisawi DM (1998) Seed germination of-Amygdalus arabica Oliv.-as influenced by stratification and certain plant bioregulators: XXV International Horticultural Congress, Part 7: Quality of Horticultural Products 517, pp. 21-30.

Köse A (2014) Adıyaman İlinde doğal olarak yetişen amygdalus türlerinin ve değişik tiplerinin belirlenmesi. Yüksek Lisans Tezi. Harran Üniversitesi Fen Bilimleri Enstitüsü, Şanliurfa, pp. 6-7.

Köse A, Sakar E, Ak BE \& Oguz HI (2015) Preliminary sssessment of wild Amygdalus spp. and their different types grown naturally in Adiyaman Region, Turkey: II International Symposium on Wild Relatives of Subtropical and Temperate Fruit and Nut Crops 1074, pp. 55-58.

Leishman MR, Wright IJ, Moles AT \& Westoby M (2000) The evolutionary ecology of seed size: Seeds, the ecology of regeneration in plant communities (ed. by M Fenner) CABI, pp. 31-58.

Meikle RD (1966) Prunus L.: Flora of Iraq 2: 153170.

Michaels HJ, Benner B, Hartgerink AP, Lee TD, Rice S, Willson MF \& Bertin RI (1988) Seed size variation: magnitude, distribution and ecological correlates. Evolutionary Ecology 2: 157-166.

Miller AG \& Cope TA (1996) Flora of Arabian Peninsula and Socotra. Vol. 1. Edinburgh University Press, Edinburgh.

Rahemi A, Fatahi R, Ebadi A, Hassani D \& Chaparro JX (2009) The study of seed stratification and germination in Amygdalus species of Iran: V International Symposium on Pistachios and Almonds 912, pp. 275-279.

RBG (2020) Royal Botanic Gardens Kew, Seed Information Database. https://data.kew.org/sid.

Rouhi V, Ranjbarfardooei A \& Damme PV (2005a) Effects of gibberellic acid and temperature on germination of Amygdalus scoparia Spech seeds. Options Mediterraneennes. Serie A, Seminaires Mediterraneens 63: 397-401.

Rouhi V, Uddin MR, Damme PV (2005b) Germination, growth and dry matter accumulation of wild almond seedlings from stratified and scarified seeds. Communications in Agricultural and Applied Biological Sciences 70: 235-240.

Schmidt L (2000) Guide to handling of tropical and subtropical forest seed. Danida Forest Seed Centre, Denmark.

Shalaby MN, Ghazal AA, El-Rayes R \& Aswad NG (1997) Preliminary ecological and geobotanical investigation on wild species of almond (Amygdalus L.) in Syria.

Talhouk SN, Lubani RT, Baalbaki R, Zurayk R, Alkhatib A, Parmaksizian L \& Jaradat AA (2000) Pheno- 
typical diversity and morphological characterization of Amygdalus L. species in Lebanon. Genetic Resources and Crop Evaluation 47: 93-104.

Yaltirik F (1971) Memleketimizde az taninan bir odunsu bitki. Forestist 21: 80-85.

Yıldız D (2013) Kahramanmaraş-Dereköy yöresindeki bir dağ çağlası (Amygdalus arabica Oliv.) populasyonunda fenolojik gözlemler (MSc thesis). Kahramanmaras Sutcu İmam Üniversitesi.

Yılmaz M (2010) Doğu Kayını (Fagus orientalis Lipsky) Tohumlarının Farklı sıcaklıklardaki Çim- lenme Tutumları, SDÜ Orman Fakültesi Dergisi Seri: A 1: 1-8.

Yilmaz M \& Ok T (2015) Seed characteristics of Flueggea anatolica, an endangered forest shrub species. Dendrobiology 74: 59-67.

Yılmaz M, Tonguç F \& Ok T (2014) Türkiye'nin endemik ağaçlarından Fraxinus ornus subsp. cilicica tohumlarının saklanmasının tohum canlılığı ve çimlenmesi üzerine etkisi. SDÜ Orman Fakültesi Dergisi 15: 15-20. 